\title{
How to Manage an Effective Laboratory for Science Learning in Schools?
}

\author{
Nyoto Suseno $^{1, \mathrm{a})}$, Riswanto ${ }^{1, \mathrm{~b})}$, M. Barkah Salim ${ }^{1, \mathrm{c})}$, \\ Dedy Hidayatullah Al- Arifin ${ }^{1, \mathrm{~d})}$, I Gede Rasagama ${ }^{2, \mathrm{e}}$ \\ ${ }^{1}$ Universitas Muhammadiyah Metro, Indonesiao \\ ${ }^{2}$ Politeknik Negeri Bandun, Indonesia
}

\begin{abstract}
$\bowtie$ : ${ }^{\text {a)}}$ nyotoseno@gmail.com, ${ }^{\mathrm{b}}$ riswanto@ummetro.ac.id, ${ }^{\mathrm{c}}$ barkah_um@yahoo.com,

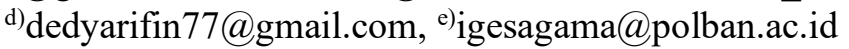

\begin{abstract}
The role of school laboratories is vital in helping junior high school students learn science. Many schools have laboratory facilities but are underutilized. This study aims to optimize the role of school laboratories through action research. In three cycles, the writer carried out the SMP Negeri 2 Metro research and SMP Negeri 6 Metro. The first cycle carried out technical guidance to the laboratory manager. Still, the results were not as expected due to communication problems to understand the principal's importance of incomplete laboratory improvement. The second cycle is carried out by mentoring the laboratory management. This includes the making of the laboratory management, inventory, and labeling, and creating work programs. This cycle two treatment also has not shown the results as expected. The reflection results found that the root of the problem was that the teachers and the laboratory manager believed that practicum activities needed time. So, it had to be carried out outside of class hours to require additional time, effort, and cost. To overcome this problem, in the third cycle, a workshop on making a practicum guide and Standard Operating Procedure (SOP) of practicum was developed according to the lesson schedule, then a trial was conducted. Data collection uses documentary, interview, and Focus Group Discussion (FGD) methods to explore the root of the problem and the solution. Data processing uses a qualitative approach with steps: data collection, selection, and grouping, tabulation, description, interpretation, and conclusions. Based on the results of action research data analysis, it can be concluded: First, management improvement and inventory of laboratory tools and materials as well as making practical SOPs, which are effective in optimizing the role of science laboratories in supporting the learning process; Second, the use of SOP practicum according to the lesson schedule is quite efficient in saving time, effort, and costs. According to the results of this study, it is recommended that for the laboratory to be optimal in supporting learning, laboratory management must be orderly equipped with SOPs, and inventory of tools and materials must be good.
\end{abstract}

Keywords: science learning, laboratory management, practicum activities, effective

\section{INTRODUCTION}

Middle school children aged between 12 and 15 years, children of this age are in a level of thinking between concrete and formal. According to Piaget, the phase of the intellectual development of children: the pre-operational phase (ages 5-6 years), the concrete operation phase (13-14 years old), and the formal operation phase (over 14 years old). The substantial operation phase of the child has 
been able to solve problems with their thoughts, and the proper operation phase of the child can connect various variables, make predictions and evaluate through observation (Nasution 2000). The laboratory is essential to connect field conditions (concrete operations) with laboratory conditions (formal operations) as a bridge to facilitate the adaptation process of students' thinking in learning (Slavin 2019; Suseno 2012).

New knowledge will feel odd if it is not relevant to the experience (Wiggins et al. 2005). Learning new knowledge will be more meaningful if it is related to the knowledge or experience that is already owned (Suseno 2014). For example, in studying the "electric current," the abstract phenomenon can be felt with other senses. "Electric current" should be assisted with an experimental device to show the existence of the electric current phenomenon and relate with their experiences, such as the phenomenon of electric lights or a feeling of electric shock. So this phenomenon to be easily understood by students. Therefore, the role of the practicum laboratory is crucial in helping students' thinking processes (Suseno \& Harjati 2016).

According to Jones et al. (2016) the laboratory can strengthen students' understanding through facts. Gandhi et al. (2016) show that laboratory activities can improve two aspects: the development of the experiment and students' abilities. Also, another research from Suseno et al. (2011) shows that practicum combined with analogy can help discover abstract concepts. Yolanda (2011) found that practicum can improve critical thinking skills. The results of other studies, Dittrich et al. (2016) found that laboratory experiments on entropy events can enhance understanding of intuition through knowledge and experience. Then Kemp et al. (2016) found that experiments can show the phenomenon of light with many of its essential forms in relatively straightforward localized waves.

The above study results reveal that the role of the practicum is significant in science learning. Rustaman (2010) suggests four reasons for the importance of practicum activities, namely: (1) it can generate learning motivation, (2) it can develop science process skills (Saputra et al. 2021)), (3) become a vehicle for learning with a scientific approach (Liana et al. 2020), and (4) strengthen students' understanding through discovery (Haryadi \& Pujiasturi 2019). Kohnle et al. (2012) revealed that students could understand the concepts and processes with experimental activities. Suseno (2012) found that the practical method can develop attitude, psychomotor, and cognitive learning outcomes.

The role of the laboratory is significant, both in the pedagogical aspects (such as the development of learning methods and strategies) and the elements of developing students' abilities (mind-on and hands-on). Riswanto \& Dewi (2017) revealed that practicum learning could develop science process skills and form the character of responsibility and collaboration. With experimental activities, learning takes place as experts find theories, including observation, formulating problems, making hypotheses, conducting experiments, analyzing data, and making conclusions called learning using a scientific approach.

The study of Suseno \& Riswanto (2017) found several obstacles in the use of laboratories: 1) laboratory head officials are only an additional profession, 2) laboratory personnel have not mastered laboratory work, 3) teacher motivation to use laboratories in learning is lacking, 4) laboratory management is not good, 5) tools and materials experiments are challenging to find, 6) laboratory room is often used for other irrelevant activities.

Science laboratory management needs to be improved to support the learning process. According to Suseno et al. (2014) there are at least six types of inventory data for the administration of science laboratories: format A (lab space plan), format B (lab facilities), format C (practicum equipment data), format $\mathrm{D}$ (practicum material data), format $\mathrm{E}$ (human resource data) and format $\mathrm{F}$ (laboratory activity schedule). Novianti (2011) found that: the contribution of science laboratory management and student learning motivation is quite substantial on the effectiveness of the learning process. Paetkau et al. (2013) found that simulations can help students prepare for practicum by up to $20 \%$. The results of Suseno \& Riswanto (2017) found that when laboratory management is improved, the implementation of practicum according to the lesson schedule does not interfere with other subjects.

The preliminary study results found that secondary school science laboratory infrastructure standards had been fulfilled, but the laboratory personnel was insufficient. Therefore, it is necessary to evaluate the management of laboratories in the school (Gustini \& Wulandari 2020). Laboratory human resources cannot yet manage the laboratory; guidance and assistance in laboratory management are needed (Zuraida \& Cahyadi 2021). Laboratory management is essential to empowering the school's 
laboratory facilities (Sauri 2020; Yohana \& Apriana 2020). Good laboratory management must have fundamental functions, organization, effective and efficient use of facilities, administration, and safety.

Work security (Astuti 2020). Need to develop inventory system and laboratory administration based on information technology (Arsul et al. 2021; Khaira et al. 2020). In addition, there also needs to be a culture of occupational safety and security in the laboratory (Trasmini et al. 2021).

Educators and laboratory personnel have attended many training programs but have not been implemented in schools. The problems include: individual aspects of training participants do not have the motivation to work better, aspects of school management that do not facilitate the implementation of training results, and aspects of training materials that are not suitable for school needs. Therefore, it is necessary to conduct school action research entitled "How to Manage an Effective Laboratory for Science Learning in Schools?".

\section{METHODS}

Writer researched in SMP Negeri 2 Metro and SMP Negeri 6 Metro. This study used a school action research design to empower science laboratories in secondary schools. Several treatment cycles to improve the science laboratory management system to create efficient practicum activities in supporting the learning process.

The first treatment, technical guidance, is carried out to laboratory staff (Head of Labs and Laboratory Assistants), which includes management, administration of tools and practicum materials, and preparation of practicum programs. After that, reflection is carried out to see the impact and the obstacles. The writer determined the subsequent treatment based on the findings in first cycle.

This school action research includes three cycles, and first cycle is carried out by technical guidance of laboratory personnel. The second cycle, assistance in managing laboratory tools and materials, especially laboratory equipment and materials inventory. The third cycle, with treatment, assistance in preparing laboratory management manuals, creating work programs, and making standard operating procedures (SOPs) for practicum implementation.

Data collection before and after treatment was carried out to determine the impact of each treatment given. Data collection was carried out through tests, observation, interviews, and documentation. The test is conducted in first cycle to measure the mastery of laboratory management before and after technology guidance. Discussions, comments, and documentation are used to explore the constraints of implementing technology guidance action plans.

Based on these data, reflection is carried out (involving researchers, laboratory personnel, and teachers) to analyze constraints and choose the next treatment step. All data is then processed and analyzed by comparing the conditions before and after treatment. Pre-test and post-test data were obtained using normalized N-gain. Stages of qualitative data analysis include examination and selection of data, grouping, and classification, tabulation of data, data analysis by deciphering and connecting data with guidance on the focus of research. Then make interpretations according to research problems and questions, and make conclusions.

\section{RESULTS AND DISCUSSION}

\section{Condition}

SMP Negeri 2 Metro and SMP Negeri 6 Metro already have science laboratory facilities and infrastructure and head of laboratory and laboratory assistant. Laboratory utilization is not optimal due to the following problems:

1. The laboratory staff has not met the standards.

2. Laboratory personnel has not mastered the principles and concepts of laboratory management.

3. Laboratory equipment and materials have not been properly administered.

4. Do not have a laboratory management manual and SOP.

5. The work program is not implemented.

6. The science laboratory has not been used optimally in supporting the learning process.

Existing administrative documents: 
1. Letter of assignment as laboratory head as an additional assignment.

2. Letter of assignment as a laboratory assistant.

3. Organizational structure.

4. Incomplete laboratory inventory book of tools and materials.

5. Several practical guidelines.

6. Order.

7. Student attendance list.

8. Laboratory works safety documents.

The results of the interviews revealed that all documents had not been implemented optimally. Practical activities are incidental when the teacher takes the initiative to carry out the practicum.

\section{Treatment Cycle 1: Technical Guidance in Laboratory Management}

Treatment cycle 1 provides technical guidance to laboratory staff (head of laboratory and laboratory assistant) with a pattern of 53 lesson hours (TABLE 1).

TABLE 1 Material of technical guidance for laboratory staff.

\begin{tabular}{llc}
\hline No & \multicolumn{1}{c}{ Material } & Lesson hours \\
\hline 1. & Policy on Science Laboratories in Indonesia & 2 hours \\
2. & Review the curriculum & 3 hours \\
3. & Culture and National Character & 2 hours \\
4. & Optimization of Laboratory Utilization & 3 hours \\
5. & Laboratory Management & 3 hours \\
6. & Laboratory Administration & 3 hours \\
7. & Standard Operating Procedures (SOP) & 3 hours \\
8. & Creating a Laboratory Workplan & 3 hours \\
9. & Occupational Health and Safety & 2 hours \\
10. & Designing Practicum Guide & 5 hours \\
11. & Laboratory Equipment and Materials Inventory & 5 hours \\
12. & Practice using Measuring and Calibration Tools & 4 hours \\
13. & Maintenance of Practicum Equipment & 3 hours \\
14. & Practicum Equipment Repair & 2 hours \\
15. & Planning Field Practices & 2 hours \\
16. & Designing Simple Practicum Tools & 4 hours \\
17. & Performance Assessment & 2 hours \\
18. & Follow up Plan $\quad$ Sum of Lesson Time & 2 hours \\
& & $\mathbf{5 3}$ hours \\
\hline
\end{tabular}

The target of technical guidance is laboratory staff to master the concepts, principles, and techniques of science laboratory management. After being evaluated, the results are obtained in TABLE 2.

TABLE 2. Data on the achievements of technical guidance participants

\begin{tabular}{cc}
\hline Data & Score (scale 100) \\
\hline Pre-test mean score & 61 \\
Post-test mean score & 73 \\
Gain (Normal) & $30.8 \%$ \\
\hline
\end{tabular}

Next, data was collected related to implementing follow-up plans for technical guidance participants. Observation data are as follows:

1. Participants have mastered laboratory management but have not found the first step.

2. The technical guidance participants have submitted follow-up plans to the school principal.

3. School policy has not prioritized the program for improving the management of science laboratories due to budget constraints.

Based on the data, reflection is carried out to reveal problems and alternative solutions as follows:

1. School managers have not realized the importance of science laboratories, so it needs to be communicated that the role of laboratories is crucial in supporting learning. This is in the opinion of (Sutoerno 2013) 
2. Assistance is needed in improving laboratory management to optimize the use of science laboratories to support the learning process (Zuraida \& Cahyadi 2021).

\section{Treatment Cycle 2: Assistance in Laboratory management}

In cycle 2, there is socialization and assistance in laboratory management, especially in improving laboratory equipment and materials management and inventory. Cycle 2 treatment data is presented in TABLE 3.

TABLE 3. Cycle 2 Treatment data on assistance in laboratory management

\section{Workshop on Manual Laboratory Management}

Target: Produce a laboratory management manual Result:

Participant: Principal, Head of Laboratory,

Realized of Science Laboratory Management Manual Policy

Laboratory Assistant \& Teacher

\section{Carry out Inventory, Labeling and Storage of Laboratory Equipment and Materials}

Target: arranged inventory data of laboratory equipment and Result:

materials

Participant: Laboratory assistant \& Head of Laboratory
Inventory data for laboratory equipment and materials SMPN 2 Metro has 245 types of laboratory equipment with a total of 2,133 units, 2,109 of which are in good condition and 24 are damaged.

SMPN 6 Metro has 196 types of laboratory equipment with a total of 907 units all in good condition.

\section{Laboratory Programs and Plans}

Target: Compiled an annual work plan and program according Result: to the conditions and needs of the school. Participant: Principal, Head of Laboratory, An annual work plan and program is compiled for SMPN 2 Laboratory Assistant \& Teacher

After assisting in laboratory management, three documents were obtained: 1) Lab management manual document 2) Inventory of tools and materials 3) Annual work program. Physically, laboratory equipment and materials are well arranged and easily accessible for practicum activities. Some of the deficiencies in cycle 2 are:

1. The annual work program is not going well. One of the reasons is that the communication between teachers and laboratory managers is not going well.

2. Not all teachers make practicum instructions or student worksheets.

3. Science teachers think that practicum activities require a lot of time, so they need additional hours.

Based on the result of monitoring in cycle two, the Science Lab has not been implemented optimally. Reflection cycle 2 recommends the following:( 1) It is necessary to conduct a workshop on making practicum guides according to the lesson plans by the teacher, (2) It is required to make SOP for practicum according to the lesson schedule and test its effectiveness and efficiency.

\section{Treatment Cycle 3: Workshop on Making Worksheets and SOP}

In Cycle 3, a workshop on making worksheets and SOPs were conducted as follows:

TABLE 4. Cycle 3 Treatment result data at workshops making worksheets and SOPs

\section{Workshop on Making Practicum Guides}

\begin{tabular}{ll}
\hline Target: All science teachers produce practicum & Result: \\
guides/worksheets & Each science teacher produces 5-6 practical guides/worksheets, which \\
Participant: Science Teachers & $\begin{array}{l}\text { clearly contain objectives, tools and materials, procedures, } \\
\text { data tables, and conclusion sheets. }\end{array}$
\end{tabular}

2. Making Practicum SOP according to the lesson schedule 
Target: produce SOP for practicum activities Participant: Head of Laboratory,

Laboratory Assistant \& Teacher

\section{Result:}

obtained documents:

SOP practicum according to lesson schedule

Student and teacher rules in using the science lab

\section{SOP testing for practicum implementation}

Target: Practical activities in the science laboratory are carried out according to the lesson schedule

Participant: Principal, Head of Laboratory, Laboratory

Assistant \& Teacher

\section{Result:}

Schedule of Lessons

Schedule of practicum activities practicum guide/worksheets

List of necessary laboratory equipment and materials Attendance list

Video and Photo Recording

The results of activities 1 and 2 are practical guidelines and SOPs. these two documents were used in field trials. The SOP stages for the implementation of the practicum according to schedule are as follows:

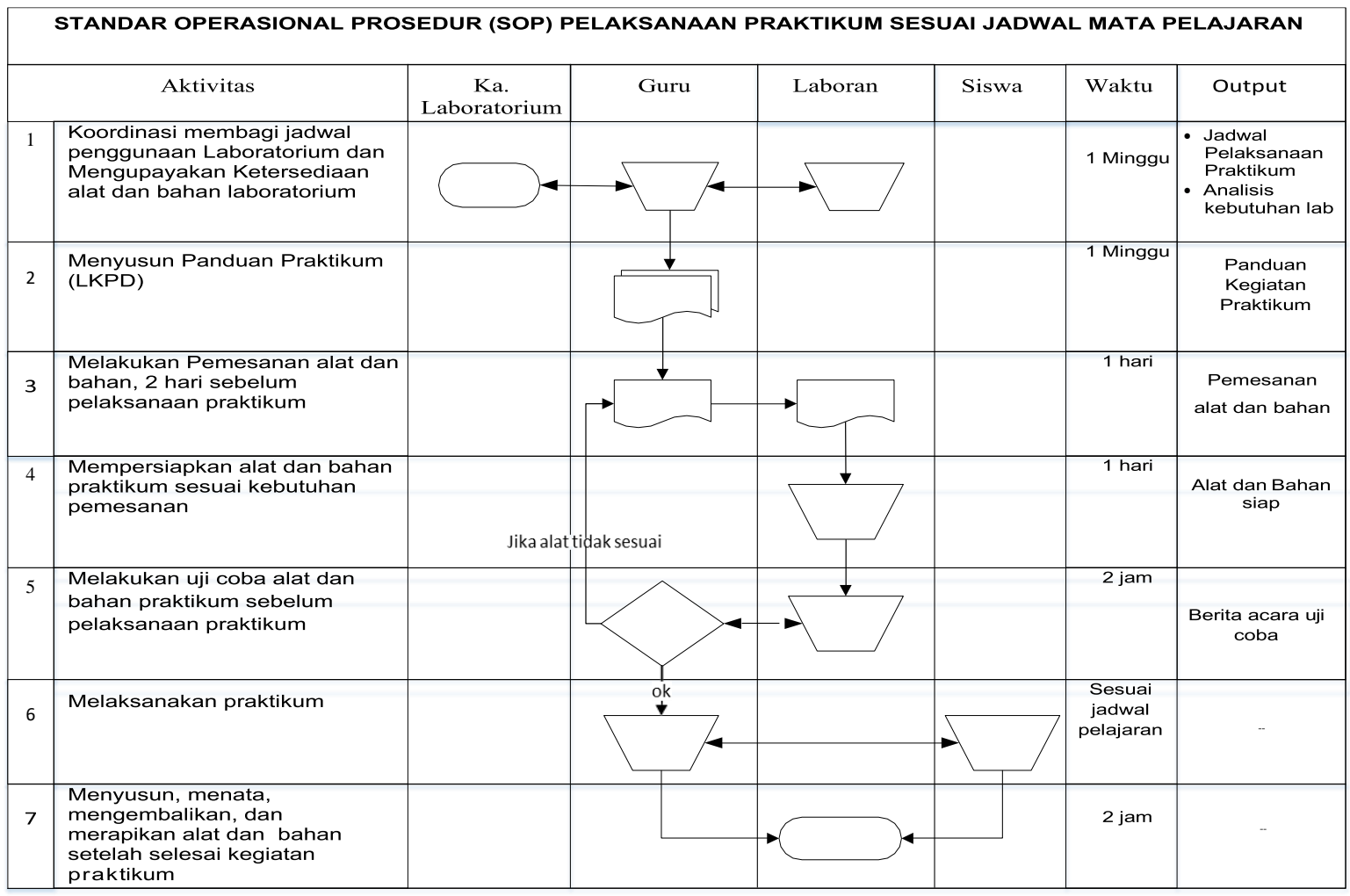

FIGURE 1. SOP flow chart for practicum activities

The results of the try-out SOP practicum for cycle 3, involving science teachers, laboratory assistants, laboratory heads, and students, obtained the data presented in TABLE 5.

TABLE 5. Result data try out SOP practicum in learning science

\begin{tabular}{clcccc}
\hline No. & Observed activities & Try Out 1 & Try Out 2 & Try Out 3 & Data Description \\
\hline 1. & $\begin{array}{l}\text { Preparation of } \\
\text { Practicum tools }\end{array}$ & 19 minutes & 14 minutes & 11 minutes & $\begin{array}{c}\text { Average prepare time } \\
\text { Was 14.7 minutes }\end{array}$ \\
$\begin{array}{l}\text { 2. } \\
\begin{array}{l}\text { The distance between } \\
\text { the classroom and the } \\
\text { laboratory Room }\end{array}\end{array}$ & 14 minutes & 20 minutes & 15 minutes & Average distance 16.3 me \\
& & & & \\
3. $\begin{array}{l}\text { Allocation of lesson } \\
\text { time }\end{array}$ & $\begin{array}{l}\text { 3 lesson hours } \\
\text { (120 minutes) }\end{array}$ & $\begin{array}{c}\text { 2 lesson hours } \\
\text { (80 minutes })\end{array}$ & $\begin{array}{c}\text { 2 lesson hours } \\
\text { (80 minutes })\end{array}$ & $\begin{array}{c}\text { Allocation time } \\
\text { 2 dan 3 lesson hours }\end{array}$
\end{tabular}




\begin{tabular}{|c|c|c|c|c|c|}
\hline No. & Observed activities & Try Out 1 & Try Out 2 & Try Out 3 & Data Description \\
\hline 4. & Opening of learning & $\begin{array}{c}28 \text { minutes } \\
\text { (More than } 8 \text { minutes } \\
\text { of the } \\
\text { Plan lesson time) }\end{array}$ & 13 minutes & 14 minutes & $\begin{array}{c}\text { Average time opening } 18.3 \\
\text { minutes }\end{array}$ \\
\hline 5. & $\begin{array}{l}\text { Time to move from } \\
\text { classroom } \\
\text { To lab }\end{array}$ & 3 minutes & 3 minutes & 4 minutes & $\begin{array}{l}\text { Average time to move } 3.3 \\
\text { minutes }\end{array}$ \\
\hline 6. & Practicum activity & 91 minutes & 65 minutes & 60 minutes & $\begin{array}{c}\text { Average time allocation to } \\
\text { practicum activity } 77 \% \text { from } \\
\text { lesson hours }\end{array}$ \\
\hline 7. & $\begin{array}{l}\text { Time to move back } \\
\text { to the } \\
\text { Classroom }\end{array}$ & 3 minutes & 3 minutes & 4 minutes & $\begin{array}{c}\text { Average time to move } 3.3 \\
\text { minutes }\end{array}$ \\
\hline 8. & $\begin{array}{l}\text { Excess learning } \\
\text { Time }\end{array}$ & 5 minutes & 4 minutes & 2 minutes & $\begin{array}{c}\text { Average access time } \\
3.7 \text { minutes }\end{array}$ \\
\hline 9. & $\begin{array}{l}\text { Storage time for } \\
\text { Practicum tools }\end{array}$ & 12 minutes & 10 minutes & 10 minutes & $\begin{array}{l}\text { Average time of } \\
\text { Storage tool } 10.7 \text { minutes }\end{array}$ \\
\hline
\end{tabular}

The try-out results showed that the practicum activities were according to the lesson schedule, did not interfere with the plans of other subjects because the spare time for practicum in the laboratory was only 3.7 minutes. Movement time from the classroom to the laboratory and back on average only takes 3.3 minutes. So that in terms of time, practicum activities guided by practicum SOPs run quite efficiently.

Practicum preparation takes an average of 14.7 minutes, while the storage time of practicum tools takes 10.7 minutes. This shows that after being given treatment:

1. Starting from technology guidance

2. Assisting laboratory management

3. Workshops on making worksheets for teachers and making SOPs

4. Practicum activities in the laboratory can be carried out efficiently without adding lesson hours outside of school schedules.

In other words, from the aspect of labor and costs, administrative reform and the use of SOPs are very efficient. This is in the opinion of (Fikri et al. 2020).

After assistance is provided in improving laboratory management and an inventory of tools and materials is carried out, the practicum assistance can optimize the role of the laboratory effectively in supporting the learning process. These results align with some articles (Khaira et al. 2020; Sauri 2020; Yohana \& Apriana 2020; Zuraida \& Cahyadi 2021). In addition, this treatment is also effective in overcoming teacher problems in laboratory use, where this assistance facilitates teachers and students in practicum activities.

\section{CONCLUSION}

Overall, the research results show that Assistance in improving laboratory management, administration, inventory of tools and materials, and the existence of practicum SOPs so that teachers, students, and laboratory assistants can optimize the laboratory effectively and efficiently in supporting the learning process. Some conclusions that can be stated:

1. Management improvement and inventory of laboratory tools and materials, as well as making practical SOPs, which effectively optimize the role of science laboratories in supporting the learning process.

2. Teachers, students, and laboratory assistants can use the science laboratory to support the science learning process effectively after laboratory management and administration are arranged in such a way as to make it easier for teachers and students in practicum activities.

3. he existence of practicum SOPs makes practicum activities efficient in time, effort, and cost.

According to the results of this study, it is recommended that for the laboratory to be optimal in supporting learning, laboratory management must be orderly equipped with SOPs, and inventory of tools and materials must be good. 


\section{REFERENCES}

Arsul, A, Papuangan, M, Hizbullah, I \& Dosu, A 2021, 'Perancangan Sistem Informasi Laboratorium Komputer Berbasis Website di Universitas Pasifik Morotai', Jurnal Teknik SILITEK, vol. 1, no. 1, pp. 46-52.

Astuti, R 2020, 'Manajemen Laboratorium yang Cerdas, Cermat, dan Selamat', CV Jejak (Jejak Publisher.

Dittrich, W, Drosd, R, Minkin, L \& Shapovalov, AS 2016, 'The Law of Entropy Increase-A Lab Experiment', The Physics Teacher, vol. 54, no. 6, pp. 348-350.

Fikri, M et al. 2020, 'Konsep Dasar Manajemen Pendidikan \& Peran Standar Operasional Prosedur (SOP)', Najmu Books Publishing.

Gandhi, PR, Livezey, JA, Zaniewski, AM, Reinholz, DL \& Dounas-Frazer, DR 2016, 'Attending to experimental physics practices and lifelong learning skills in an introductory laboratory course', American Journal of Physics, vol. 84, no. 9, pp. 696-703.

Gustini, N \& Wulandari, W 2020, 'Manajemen Laboratorium Sains untuk Meningkatkan Mutu Pembelajaran', Jurnal Isema: Islamic Educational Management, vol. 5, no. 2, pp. 231-244.

Haryadi, R \& Pujiastuti, H 2019, 'Discovery Learning based on Natural Phenomena to Improve Students' Science Process Skills', Jurnal Penelitian \& Pengembangan Pendidikan Fisika, vol. 5, no, 2, pp. 183-192.

Jones, JA, D’Addario, AJ, Rojec, BL, Milione, G \& Galvez, EJ 2016, 'The Poincaré-sphere approach to polarization: Formalism and new labs with Poincaré beams', American Journal of Physics, vol. 84 , no. 11 , pp. 822-835.

Kemp, KJ, Barker, S, Guthrie, J, Hagood, B \& Havey, MD 2016, 'One-dimensional light localization with classical scatterers: An advanced undergraduate laboratory experiment', American Journal of Physics, vol. 84, no. 10, pp. 746-751.

Khaira, U, Aryani, R, Utomo, PEP \& Weni, I 2020, 'Rancang Bangun Sistem Informasi Manajemen Laboratorium Fakultas Sains dan Teknologi Universitas Jambi', Senamika, vol. 1, no. 2, pp. 47-61.

Kohnle, A, Brown, CTA, Rae, CF \& Sinclair, BD 2012, 'Problem-based labs and group projects in an introductory university physics course', Physics Education, vol. 47, no. 4, p. 476.

Liana, YR, Linuwih, S \& Sulhadi, S 2020, 'The Development of Thermodynamics Law Experiment Media Based on IoT: Laboratory Activities Through Science Problem Solving for Gifted Young Scientists', Jurnal Penelitian \& Pengembangan Pendidikan Fisika, vol. 6, no. 1, pp. 51-64.

Nasution, S 2000, 'Berbagai pendekatan dalam proses belajar dan mengajar'.

Novianti, NR 2011, 'Kontribusi pengelolaan laboratorium dan motivasi belajar siswa terhadap efektivitas proses pembelajaran', Jurnal Pendidikan MIPA, Edisi Khusus, vol. 1, pp. 158-166.

Paetkau, M, Bissonnette, D \& Taylor, C 2013, 'Measuring the effectiveness of simulations in preparing students for the laboratory', The Physics Teacher, vol. 51, no. 2, pp. 113-115.

Riswanto, R \& Dewi, NAK 2017, 'Peningkatan keterampilan proses sains melalui pembelajaran berbasis laboratorium untuk mewujudkan pembelajaran berkarakter', Jurnal Riset Dan Kajian Pendidikan Fisika, vol. 4, no. 2, pp. 60-65.

Rustaman, NY 2010, 'Pengembangan Pembelajaran Sains Menggunakan Kemampuan Dasar Bekerja Ilmiah', Bandung: FMIPA UPI, pp. 211-247.

Saputra, IGPE, Harnipa, H \& Akhfar, M 2021, 'Development of Science Learning Device Oriented Guided Inquiry with Virtual Laboratory to Train Science Process Skills of Junior High School Students in Kendari', Jurnal Penelitian \& Pengembangan Pendidikan Fisika, vol. 7, no. 1, pp. 1322. 
Sauri, RS 2020, 'Manajemen Laboratorium IPA dalam Meningkatkan Prestasi Belajar Siswa di SMP', Nusantara Education Review, vol. 3, no. 1, pp. 99-108.

Slavin, RE 2019, 'Educational psychology: Theory and practice'.

Suseno, N 2012, 'Peran praktikum dalam mengembangkan kemampuan dan karakter mahasiswa calon guru fisika pada mata kuliah keahlian program studi (Studi kasus pada perkuliahan elektronika dan listrik magnet Membangun Karakter Guru Dan Dosen Untuk Mewujudkan Pendidikan Berkarakter', Paper Presented at Seminar Nasional Pendidikan Ke-1 Universitas Muhammadiyah Metro, Metro, pp. 132-139.

Suseno, N 2014, 'Pemetaan Analogi Pada Konsep Abstrak Fisika', Jurnal Pendidikan Fisika, vol. 2, no. 2, pp. 1-10.

Suseno, N \& Harjati, P 2016, 'Experiment Role in Developing Metacognition Ability of Teachers' Prospective', International Advisory Board, p. 307.

Suseno, N \& Riswanto, R 2017, 'Sistem Pengelolaan Laboratorium Fisika Untuk Mewujudkan Pelaksanaan Praktikum Yang Efisien’, Jurnal Pendidikan Fisika, vol. 5, no. 1, pp. 76-86.

Suseno, N, Partono \& Harjati, P 2011, 'Memadukan Alat Peraga dan Analogi sebagai Upaya Menerapkan Inkuiri dalam Perkuliahan Konsep Abstrak Listrik Magnet', Jurnal Nuansa Pendidikan, vol. 15, pp. 1-8.

Suseno, N, Partono, Mulyani, H, Widowati, H \& Sutanto, A 2014, 'Buku panduan kepala laboratorium sekolah/madrasah', Kota Metro: Lembaga Penelitian UM Metro Press.

Sutoerno, N 2013, 'Manajemen Laboratorium dalam Mendukung Pembelajaran Berbasis Teknologi Informasi dan Komunikasi di Sekolah Menengah Pertama Negeri 1 Pakem Kabupaten Sleman', Jurnal Ilmiah Tut Wuri Handayani, vol. 2, no. 3, pp. 159-167.

Trasmini, SW, Sunarto, D \& Ariyanti, NA 2021, 'Keselamatan dan Kesehatan Kerja Di Laboratorium Biologi', Syntax Idea, vol. 3, no, 12, pp. 2768-2773.

Wiggins, G \& McTighe, J 2005, 'Understanding by design (2nd ed.). Alexandria, VA: Association for Supervision and Curriculum Development ASCD', Colombian Applied Linguistics Journal, vol. 19, p. 140.

Yohana, PA \& Apriana, H 2020, 'Pengembangan Sistem Informasi Manajemen Laboratorium Berbasis Web Pada Politeknik Negeri Banjarmasin', Jurnal Elektronika Listrik Dan Teknologi Informasi Terapan, vol. 1, no. 2, pp. 25-31.

Yolanda, BT et al. 2011, 'Implementasi Pembelajaran Menggunakan Praktikum pada Pembelajaran Konsep Metabolisme untuk Meningkatkan Kemampuan Berpikir Kritis', Jurnal Pendidikan MIPA, vol. 12 , no. 1, pp. 59-66.

Zuraida, Z \& Cahyadi, R 2021, 'Sistem pengelolaan laboratorium pengujian bahan untuk mewujudkan pelaksanaan praktikum yang efisien', ARMATUR: Artikel Teknik Mesin \& Manufaktur, vol. 2, no. 1, pp. 7-11. 
